\title{
3D-Modelling of Charlemagne's Summit Canal (Southern Germany)_Merging Remote Sensing and Geoarchaeological Subsurface Data
}

\author{
Johannes Schmidt ${ }^{1, *(\mathbb{D}}$, Johannes Rabiger-Völlmer ${ }^{1}$, Lukas Werther ${ }^{2}\left(\mathbb{D}\right.$, Ulrike Werban $\left.{ }^{3}{ }^{(}\right)$, \\ Peter Dietrich ${ }^{3}$, Stefanie Berg ${ }^{4}\left(\mathbb{0}\right.$, Peter Ettel ${ }^{2}$, Sven Linzen ${ }^{5}$, Andreas Stele ${ }^{6}$, Birgit Schneider ${ }^{1}$ \\ and Christoph Zielhofer ${ }^{1}$ \\ 1 Physical Geography, Leipzig University, D-04103 Leipzig, Germany; \\ j.rabiger-voellmer@uni-leipzig.de (J.R.-V.); bschneid@rz.uni-leipzig.de (B.S.); zielhofer@uni-leipzig.de (C.Z.) \\ 2 Prehistory and Early History, Friedrich-Schiller University, D-07743 Jena, Germany; \\ lukas.werther@uni-jena.de (L.W.); P.Ettel@uni-jena.de (P.E.) \\ 3 Helmholtz Centre for Environmental Research UFZ, Department Monitoring and Exploration Technologies, \\ D-04318 Leipzig, Germany; ulrike.werban@ufz.de (U.W.); peter.dietrich@ufz.de (P.D.) \\ 4 Bavarian State Department of Cultural Heritage BLfD, D-80539 Munich, Germany; \\ Stefanie.Berg@blfd.bayern.de \\ 5 Leibniz Institute of Photonic Technology IPHT, D-07745 Jena, Germany; sven.linzen@leibniz-ipht.de \\ 6 Institute of Geography, Osnabruck University, D-49074 Osnabruck, Germany; astele@uni-osnabrueck.de \\ * Correspondence: j.schmidt@uni-leipzig.de; Tel.: +49-34132966
}

Received: 11 March 2019; Accepted: 6 May 2019; Published: 9 May 2019

check for updates

\begin{abstract}
The Early Medieval Fossa Carolina is the first hydro-engineering construction that bridges the Central European Watershed. The canal was built in 792/793 AD on order of Charlemagne and should connect the drainage systems of the Rhine-Main catchment and the Danube catchment. In this study, we show for the first time, the integration of Airborne LiDAR (Light Detection and Ranging) and geoarchaeological subsurface datasets with the aim to create a 3D-model of Charlemagne's summit canal. We used a purged Digital Terrain Model that reflects the pre-modern topography. The geometries of buried canal cross-sections are derived from three archaeological excavations and four high-resolution direct push sensing transects. By means of extensive core data, we interpolate the trench bottom and adjacent edges along the entire canal course. As a result, we are able to create a 3D-model that reflects the maximum construction depth of the Carolingian canal and calculate an excavation volume of approx. $297,000 \mathrm{~m}^{3}$. Additionally, we compute the volume of the present dam remnants by Airborne LiDAR data. Surprisingly, the volume of the dam remnants reveals only $120,000 \mathrm{~m}^{3}$ and is much smaller than the computed Carolingian excavation volume. The difference reflects the erosion and anthropogenic overprint since the 8th century AD.
\end{abstract}

Keywords: 3D-modelling; airborne LiDAR data; cultural heritage; digital terrain model; GIS; Fossa Carolina; early middle ages; direct push sensing; SQUID magnetic prospection

\section{Introduction}

The Central European Watershed divides the Rhine-Main catchment and the Danube catchment. During the Early Middle Ages, navigable waterways were one of the most important transportation, communication and economic exchange routes in Central Europe [1,2]. In the early 790s AD, Charlemagne decided to link the Danube and Rhine-Main catchment by the construction of a canal between Altmühl and Swabian Rezat rivers. Thus, he wanted to create an important node within the waterway network in the expanding the Franconian Empire [3-5]. This important hydro-technical 
construction in the Early Middle Ages is one of the spatially largest features of cultural heritage in Bavaria.

The archaeological research on the canal reaches back to the beginning of the 20th century with a publication of Beck [6]. The time before that was characterised by chronicles, oral traditions and descriptions [7]. During the 20th century, several archaeological surveys were conducted. There is a long-lasting debate on the volume of the moved material for the construction and subsequently on the number of workers that were needed [6,8-10]. Former studies estimated the volume just on the basis of a few recovered cores $[8,9]$ or solely on simple observations $[6,10]$. Thus, none of these studies came to a satisfying result, mostly because of a lack of precise data of the canal extent and geometry as well as its hydro-technical concept. Therefore, a 3D-modelling approach is essential for answering these specific quantitative questions, like excavation volumes and the canal's spatial distribution.

So far, three-dimensional approaches in archaeology are mainly image-based (photogrammetric) studies describing and preserving architecture, objects and features [11-13]. Richards-Rissetto [14] sees the main advantage of 3D-views in the change from the bird eye's view in GIS to a more human perspective. These approaches are sometimes used in terms of cyber-archaeology and virtual reality for museums and education $[15,16]$.

In this study, we understand 3D-modelling as a high precision reconstruction technique in terms of ruined, buried or overprinted features. Archaeological remains, which are detectable as positive landforms can be reconstructed by means of geometric simplification of the structure [17]. Hence, it is possible to calculate the volume. Thereby, the type of simplification and the amount of complexity is crucial for a reliable result $[17,18]$. However, full form archaeological features are often reconstructed by means of archaeological excavation $[17,19]$. Mapping of these structures is mostly done by LiDAR (Light Detection and Ranging), unmanned airborne vehicles (UAV, drones; equipped with laser scanning or photogrammetric devices) or ground based differential GPS surveys [20-22].

Covered and filled archaeological features like ditches, trenches and pits are often reconstructed (with the aim of volume calculation) with methods of archaeological excavation [23]. Currently, the use of geophysical methods (Electrical resistivity tomography, electromagnetic induction, seismics) for the reconstruction of archaeological features is also becoming more common [24-27]. These methods provide fast spatial approaches to mapping, but lack detailed stratigraphic data. Direct push sensing makes an exception. This geophysical method produces high-resolution stratigraphic data [27]. Further, vibra-coring, subsequent sediment sampling and geochemical laboratory analysis are useful and widespread in geoarchaeology [28,29]. Furthermore, the combination of archaeological excavation data with geoarchaeological data is becoming more common [30,31], but there are no studies which tend to model or reconstruct a whole feature by integration of archaeological, remote sensing, geophysical and sediment core data.

Generally, 3D reconstructions depend on the spatial extent of a feature. The Fossa Carolina has a proven length of approx. $2.9 \mathrm{~km}$ and a maximum depth of approx. $11 \mathrm{~m}$ below the present surface [32]. The whole canal trench is accompanied by dams, originating from Early Medieval excavations. Therefore, a complete archaeological survey is not feasible. In addition, the deeper the structure is buried the more difficult an excavation is due to inflowing groundwater and stabilisation of the trench embankments [27,33]. Therefore, vibra-coring, direct push sensing or other geoarchaeological techniques are essential. Depending on its accuracy, the data must be integrated to generate meaningful and reliable results.

In this study, we summarise trustworthy and high precision data of the geometry of the Fossa Carolina. We merge levels from driving cores, direct push sensing and archaeological excavations. We combine these datasets with a LiDAR-based, pre-modern DTM (Digital Terrain Model) [34] with the aim of creating a high-resolution 3D-model of Charlemagne's summit canal. We present and use new direct push sensing transects, profiles of archaeological excavations and multiple driving cores. For the first time, we use LiDAR data for modelling the present dam remnants but also refer to published canal geometry data (see Table 1). 
Table 1. Depth accuracy, scale and stratigraphical resolution of trench geometry data; scale classification according to Zielhofer et al. [35].

\begin{tabular}{|c|c|c|c|c|c|c|c|c|}
\hline Technique & Number & $\begin{array}{l}\text { Name (Label in } \\
\text { Figure 2) }\end{array}$ & References & $\begin{array}{l}\text { Depth } \\
\text { Accuracy }\end{array}$ & $\begin{array}{l}\text { Lateral } \\
\text { Distances }\end{array}$ & Scale & $\begin{array}{l}\text { Resolution } \\
\text { of } \\
\text { Stratigraphy }\end{array}$ & Pace \\
\hline Excavation & 3 trenches & $\begin{array}{l}\text { “2013” (c) } \\
\text { “2016-S1” (d) } \\
\text { “2016-S2” (e) }\end{array}$ & $\begin{array}{l}\text { Werther and Feiner 2014 [33]; } \\
\text { Werther et al. } 2015 \text { [36]; } \\
\text { Werther } 2017 \text { [37] }\end{array}$ & ++ & cm-scale & $\begin{array}{l}\text { micro to } \\
\text { small }\end{array}$ & +++ & - \\
\hline Direct-push & 2 transects & $\begin{array}{l}\text { "WE-Section" (a) } \\
\text { "TheAnomaly" (b) }\end{array}$ & $\begin{array}{l}\text { Völlmer et al. } 2019 \text { [38]; } \\
\text { This study }\end{array}$ & ++ & $\begin{array}{l}12.5 \text { to } \\
50 \mathrm{~cm}\end{array}$ & $\begin{array}{l}\text { micro to } \\
\text { medium }\end{array}$ & ++ & ++ \\
\hline
\end{tabular}

As a first step, we present standard cross-section reference geometries derived from archaeological excavations and direct push sensing transects. Subsequently, we conduct our 3D-modelling approach by the transfer of the cross-section reference geometries to extensive vibra-coring positions along the entire canal course. Further, we integrate the ground truth data within the pre-modern topography to establish the 3D-model. Finally, we calculate the volume of the present dam remnants and compare both volume results in the context of the construction and decay of the Fossa Carolina.

The main objectives of our study are:

1. Integrating different geoarchaeological datasets and creating a standard routine for high precision 3D-modelling of the Carolingian excavation depth and volume.

2. Calculation of the earth excavation volume based on the Fossa Carolina 3D-model and the pre-modern DTM.

3. Calculation of the dam volume based on the present LiDAR DTM and the pre-modern DTM.

4. Comparison of both volumes from the canal trench and dams, describing the differences and their implications for the Carolingian and post-Carolingian history of the canal.

\section{Materials and Methods}

\subsection{Study Area}

Charlemagne's summit canal is located on a valley watershed between Altmühl and Swabian Rezat rivers in Middle Franconia, Bavaria, Southern Germany (Figure 1). The valley fills consist of Pleistocene sandy and loamy fluvial sediments building up the valley watershed [41] as part of the Central European Watershed (approx. $420 \mathrm{~m}$ above sea level; a.s.l.) [42]. In the South, the Altmühl River level is at an altitude of $408.3 \mathrm{~m}$ a.sl. The Altmühl is a tributary of the Danube River. To the North of the Fossa Carolina, the Swabian Rezat River, as part of the Rhine-Main catchment, is at an altitude of $413.5 \mathrm{~m}$ a.s.l. 

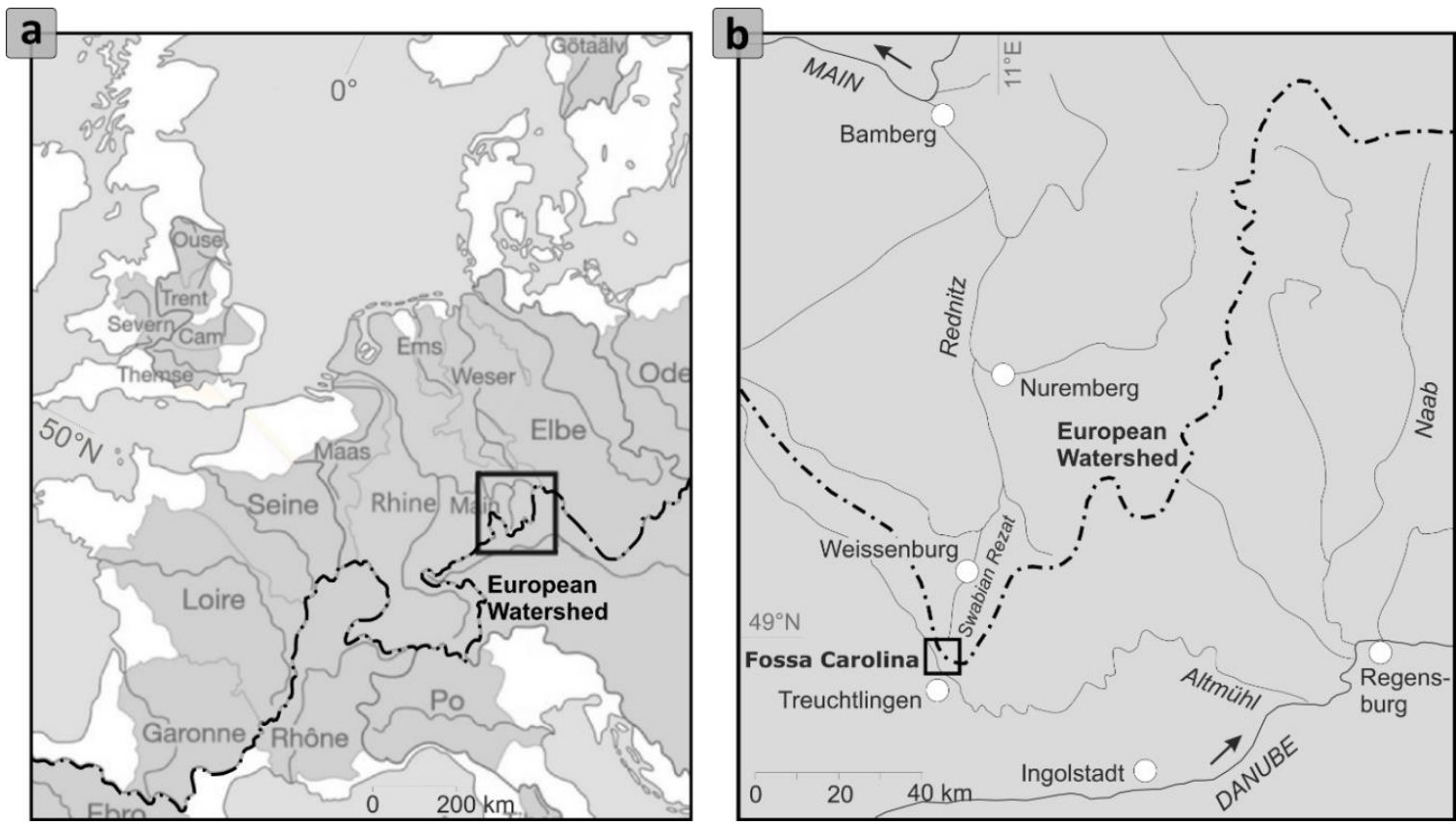

Figure 1. Geographical setting of the study area. (a) Main Central European drainage basins and the Central European Watershed. (b) Regional setting of the Fossa Carolina in relation to tributaries of the Rhine-Main drainage system and the Danube drainage system (modified after Zielhofer et al. [32]).

The canal course can be divided into five sections in relation to surface structures and trench bottom depths (see Figure 2).

(a) The Altmühl floodplain consists of late Pleistocene fluvial deposits, mainly gravels and sands. Holocene alluvial sediments accumulated subsequently with an intercalated mid-Holocene soil indicating neglectable meander migration during the late Holocene [40]. Further, Kirchner et al. [40] deduced that the Fossa Carolina was never built in this section and, therefore, the canal has never been finished.

(b) The area of the watershed (Central Section) is sedimentary characterised by Pleistocene valley fills of sandy grain sizes [3]. The sediments are of reddish to greyish colours, due to different redox conditions $[27,32,38]$. Here, large lateral dams are still present in this section. These reach altitudes up to $13 \mathrm{~m}$ above present pond level.

(c) The West-East Section marks the transition from the watershed to the Swabian Rezat floodplain. The sandy parent material is similar to the Central Section [27,38]. The lateral dams are smaller compared to the Central Section, but still prominent with altitudes up to $5 \mathrm{~m}$ above the inner trench levels.

(d) The Northern Section represents the South-North canal course parallel to the Rezat fen in the East. Sandy to loamy fluvial sediments dominate and close to the Rezat fen and a half-bog soil is developed [32]. Here, the dams are almost not visible in the field, but noticeably identifiable in the LiDAR DTM.

(e) The North-East Section is similar to the Northern Section, with clastic valley fills but the influence the organic sediments in the northernmost part increases. The Swabian Rezat floodplain (Rezat fen) is characterised by organic sediments that reach up to $3 \mathrm{~m}$ thickness [42]. Similar to the Northern Section, the dams are almost not visible in the field but can be clearly detected in the DTM. 


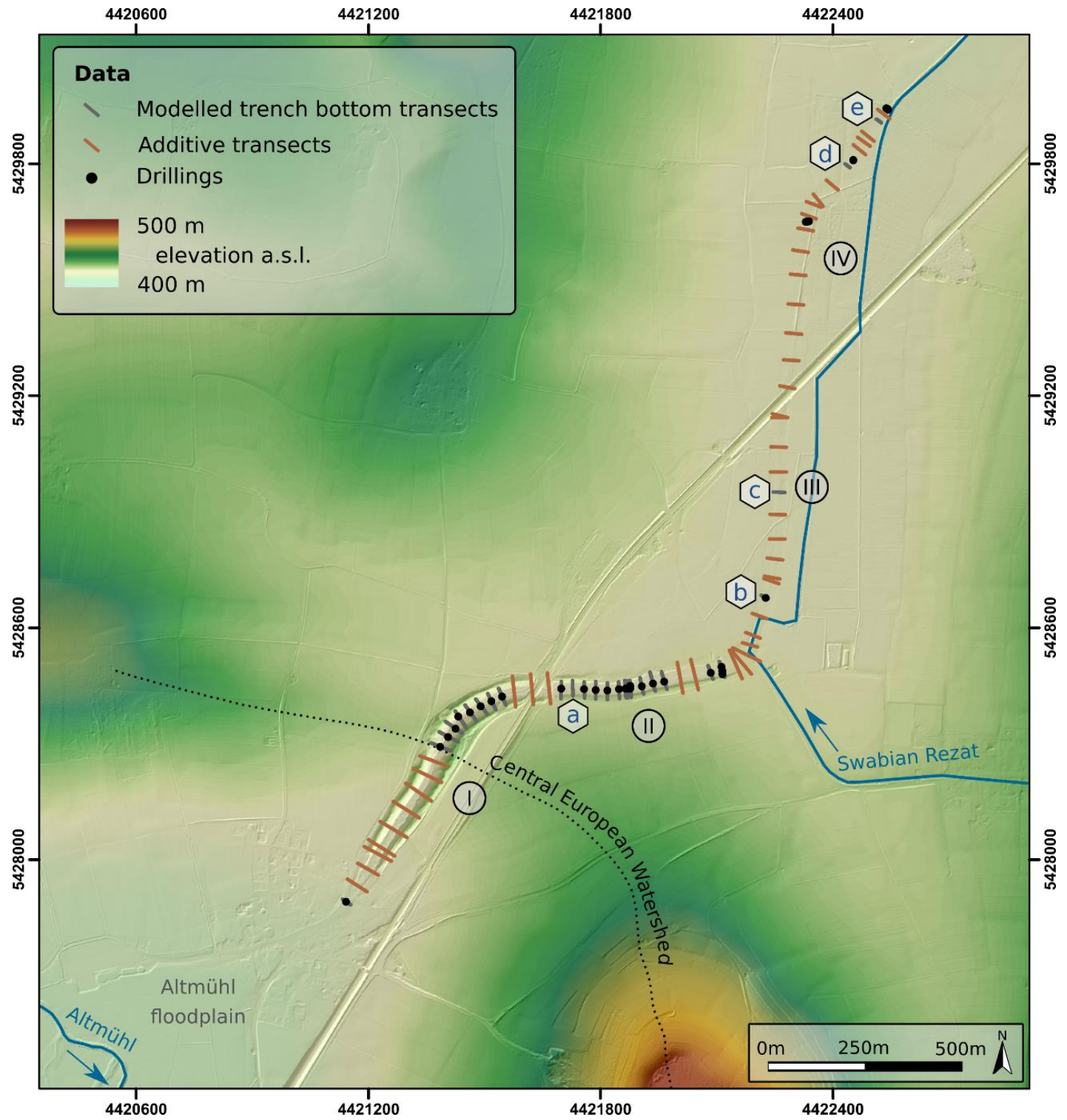

Figure 2. Local setting and course of the Fossa Carolina and its subdivision in I) Central Section, II) West-East Section, III) Northern Section, IV) North-Eastern Section. All input data for the subsequent modelling are shown, including drillings, modelled trench bottom transects and additive transects. Cross-section reference geometries (a) "West-East Section", (b) "The Anomaly" based on direct push sensing data. Cross-section reference geometries (c) "2013", (d) "2016-S1", (e) "2016-S2" based on archaeological excavations. LiDAR data have been provided by the Bavarian Land Surveying Office.

The Fossa Carolina has a length of approx. $2.9 \mathrm{~km} \mathrm{[32]} \mathrm{and} \mathrm{proof} \mathrm{of} \mathrm{the} \mathrm{Early} \mathrm{Medieval}$ summit canal was found by vibra-coring $[3,32,39,40]$, direct push sensing $[27,38]$ and archaeological excavations $[33,36]$. The canal course starts on the southern slope of the valley watershed and runs with a noticeable s-shape in the northern direction (Figure 2). The s-shape is a result of the impressive knowledge of the Carolingian constructors to make the best alignment of the canal course in relation to a minimal excavation workload [34].

According to Werther and Feiner [33] and Völlmer et al. [38] the general stratigraphy of the canal fills can be summarised as follows: the pre-Carolingian parent material consists of sandy to loamy fluvial sediments with almost no organic remains. The timber (oaks recovered during archaeological excavations, which were used to stabilise the embankments of the Carolingian canal trench) documents the construction time. The initial trench fills feature abruptly redeposited sediments with less organic 
material. Subsequently, thick organic sediments cover the initial, sandy trench fills. These organic sediments consist of peat and sapropel layers, representing open water bodies and former ponds. The youngest fills feature clastic sediments from mainly modern times. They indicate the ongoing erosion of the dams and an intensive land use with intentional levelling of the northern canal sections. Today, parts of the canal structures are fully eroded, refilled and under agricultural use. However, in the Central and West-East Section, massive dam remnants and the course of the canal are still visible (Figure 3).

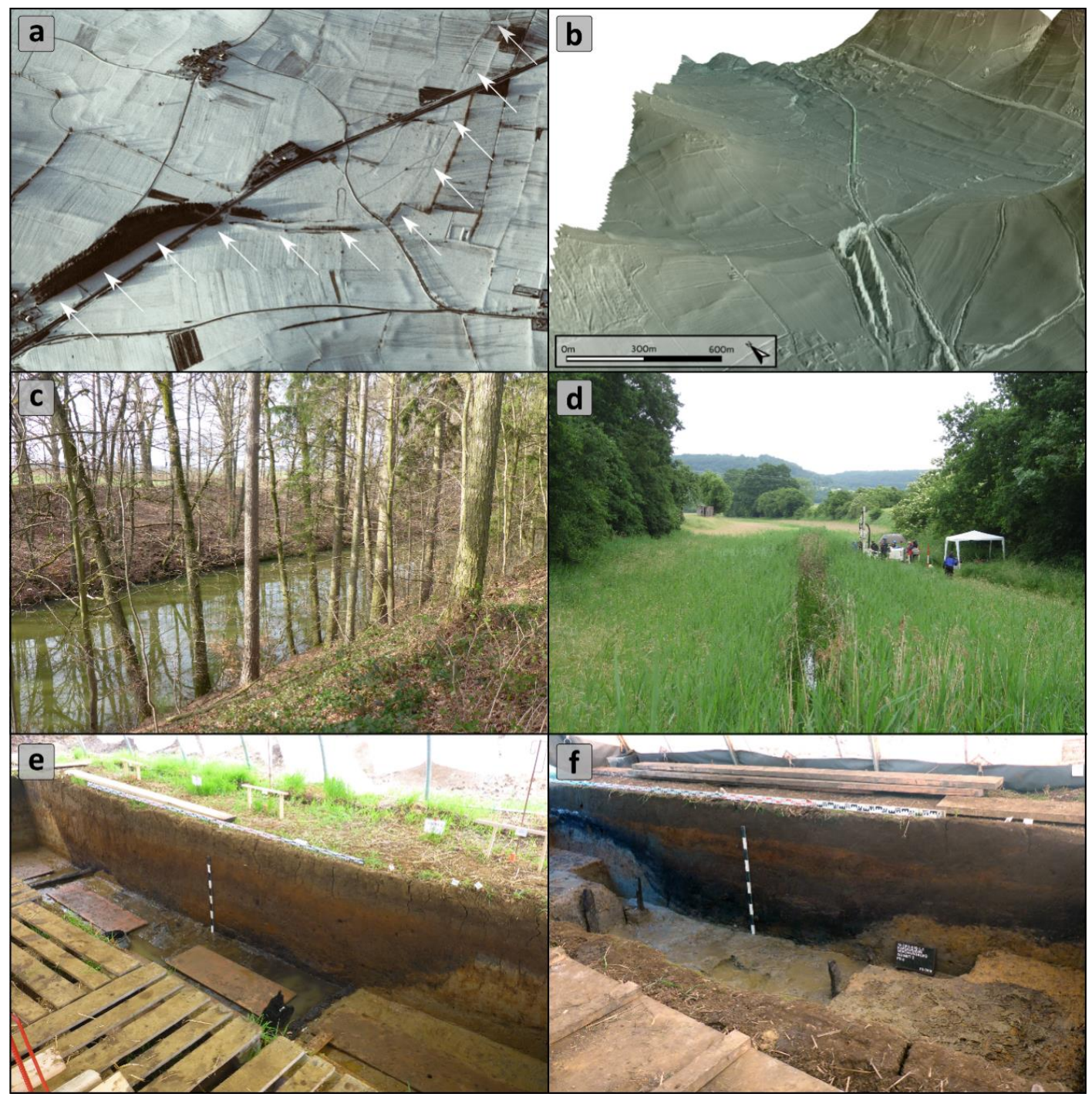

Figure 3. Impressions of the Fossa Carolina. (a) Aerial image of the canal with shadow marks highlighting terrain differences, white arrows show the canal course [43], (b) 3D view of the present Digital Terrain Model (DTM) derived from LiDAR-data, which shows the prominent dams and extent of the construction, (c) Central Section with afforested dams (Photo: Lukas Werther), (d) West-East Section with drainage ditch, lateral dams and ongoing direct push sensing (Photo: Johannes Völlmer), (e) Canal profile in the North-Eastern Section of the Fossa Carolina (2016-S1) during the excavation. The trench which has been excavated in $793 \mathrm{AD}$ is clearly visible, the trench bottom is not yet excavated. Oak piles mark the Eastern edge of the fairway (Photo: Lukas Werther; see also Figure 8b), (f) Canal profile at the Northern end of the Fossa Carolina (2016-S2) with least depth, width and excavated volume. The trench which has been excavated in $793 \mathrm{AD}$ and later filled is clearly visible. North of the profile, oak stakes mark the edges of the fairway (Photo: Lukas Werther; see also Figure 8c). 


\subsection{Data Acquisition}

\subsubsection{LiDAR Digital Terrain Model}

High-resolution airborne laser scanning data were provided by the Bavarian Land Surveying Office (provided 6 November 2012 and 8 August 2013) [44,45]. We used the derived $1 \times 1 \mathrm{~m}$ spatial resolved DTM for the localisation of the canal course and the determination of the midway position between both dam ridges. Furthermore, we use the present LiDAR DTM for the modelling and volume calculation of the present remnants of the dams.

\subsubsection{Pre-Modern Digital Terrain Model}

For the modelling of the canal geometry and its integration in the former landscape, the availability of a high-resolution pre-modern DTM is important. In this study, we use the pre-modern DTM with a spatial resolution of $1 \times 1 \mathrm{~m}$ from Schmidt et al. [34]. This model is based on the LiDAR DTM mentioned above. The DTM is purged of all modern anthropogenic structures, by removing all grid cells which are affected by anthropogenic disturbance. Finally, the remaining cells were interpolated to create a smoothed pre-modern terrain.

\subsubsection{Magnetic Survey}

We prospected the large areas of the Northern and North-Eastern Section magnetically with a fast, motorised measurement system developed for geoarchaeological issues by Linzen et al. [46]. The system is based on a set of SQUIDs (Superconducting Quantum Interference Device) which provided a very high resolution (local centimetre resolution; sensor sampling rate of $1 \mathrm{kHz}$ ) and a maximum of magnetic information $[47,48]$. Thus, we detected buried canal remains and localised their course precisely over a distance of more than $1.2 \mathrm{~km} \mathrm{[49].}$

Within the West-East Section of the canal, we conducted a manually operated Fluxgate magnetic survey to detect the canal course between the present dams. We used a Bartington Grad601 Fluxgate magnetometer and analysed and visualised the data with the software Geoplot 3.0 [32]. We mapped the precise canal course with the aid of the georeferenced magnetic maps.

\subsubsection{Vibra-Coring}

The basic data for the 3D-modelling approach represent sedimentary stratigraphic data recovered from vibra-coring, direct push sensing and archaeological excavations (Table 1). For vibra-coring, we used an Atlas Copco Cobra Pro hammer and $60 \mathrm{~mm}$ open corer. In total, we drilled 39 cores within the trench fills with coring depths between 200 and $800 \mathrm{~cm}$. Mostly, we could identify the trench bottom macroscopically but we verified it by geochemical analysis. The main contrast of the natural sediments and the first anthropogenic backfills is the organic carbon content, because the Pleistocene sediments are sterile and backfills are TOC (Total organic carbon) enriched [32].

\subsubsection{Direct Push Sensing}

Direct push sensing is a fast, minimally invasive and depth accurate tool for in-situ characterisation of sediment stratigraphies [50,51]. Steel rods with a small diameter $(38 \mathrm{~mm})$ and different probes were pushed into the unconsolidated sediments. For the data acquisition we used the colour logging tool (SCOST ${ }^{\mathrm{TM}}$, Dakota Technologies, Fargo, USA) to describe different sediment layers and their colour-dependent properties like organic content or redox characteristics [27,52]. An appropriate pace of measuring $(2 \mathrm{~cm} / \mathrm{s})$ and an integration time of $300 \mathrm{~ms}$ resulted in three values per $2 \mathrm{~cm}$. This high vertical resolution was accompanied by horizontal spacing of a minimum of $12.5 \mathrm{~cm}$. Usually, we used $50 \mathrm{~cm}$ spacing. Additionally, an electrical conductivity probe (SC-500, Keijr Engineering Inc.-Geoprobe Systems, USA) provided evidence for grain size changes [53,54]. A Geoprobe 6610DT caterpillar drove the system. For this study, we used 105 direct push colour logs divided in two 
transects (Table 1). The sensing depths ranged between 400 and $800 \mathrm{~cm}$, depending on the specific depth of the canal.

\subsubsection{Archaeological Excavations}

Based on our detailed geoarchaeological and geophysical survey, we conducted three archaeological excavations in 2013 and 2016, cutting the canal rectangular to the embankments [33,36,37]. The stratigraphy has been documented in detail in the field and validated afterwards by sedimentological analysis (grain size, organic carbon content) as well as archaeobotanical samples [36]. We measured all points of the local network with a Topcon HiPER II D-GPS. We took the absolute position official measuring points. Additionally, we proved the reference heights with an analogue levelling tool. The edges of the Carolingian trench bottom at both banks could be identified precisely with cm-accuracy, because the well-preserved timber revetments show clear signs of decay in the upper part, which was exposed to the water [36]. The trench bottom between both banks has been identified based on initial infills such as sapropel and re-located sandy material with higher organic content compared to the Pleistocene parent material. In 2013, a decimetre-uncertainty of the depth in some parts of the cross-section has been inevitable due to excavation conditions [36]. In 2016, depth accuracy is on a cm-scale in all parts of the cross-section.

\subsection{Modelling Routine}

The main challenge of our study is the combination of geoarchaeological datasets (vibra-coring data, direct push sensing data, archaeological excavation data) and the subsequent integration of the combined data within the pre-modern topography. High-resolution cross-sections of the archaeological excavations and direct push sensing transects are not equally distributed along the canal course. This is mainly due to the high effort of archaeological excavations [33] and the impassibility for the direct push caterpillar in the Central Section. Furthermore, the vibra-coring positions are also not equally distributed throughout the canal. Thus, we developed a modelling approach which suits this challenge, with four steps to create a 3D-model (Figure $4 \mathrm{a}-\mathrm{d}$ ) and two steps to calculate the excavation and dam volumes (Figure 4e,f). 

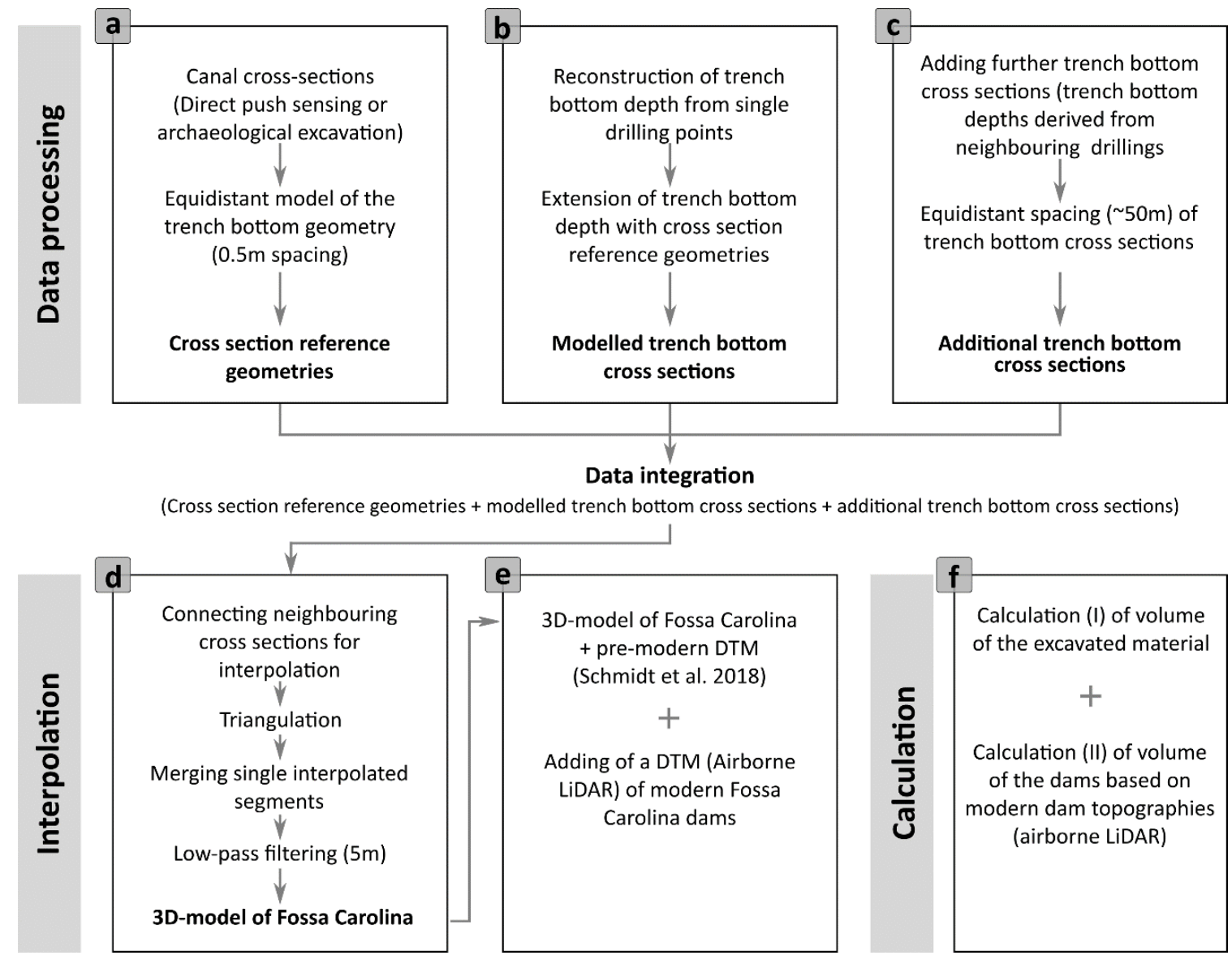

Figure 4. Flow chart of the modelling approach and subsequent calculation of volumes. (a) Creation of cross-section reference geometries, (b) Modelling of trench bottom cross-section geometries, (c) Equidistant spacing of trench bottom cross-sections, (d) 3D-model of the Fossa Carolina trench bottom, (e) 3D-model of the Fossa Carolina and the surrounding pre-modern topography, (f) Calculation of the volume of the excavated material and of the volume of the present dams.

(a) First of all, we created cross-section reference geometries that are based on high-resolution transects. Here, archaeological excavations provided the most precise data in terms of identifying the trench bottom geometry (Table 1). The spatial and vertical resolution of the direct push transects were also very high. The horizontal spacing was usually $50 \mathrm{~cm}$ but could be as small as $12.5 \mathrm{~cm}$. The vertical resolution was at centimetre scale. Hence direct push transects provided significant data for cross-section reference geometries (Figure 4a). In total, we compiled cross-section reference geometries for five cross-sections (a-e in Figure 2). These geometries are also representative for their adjacent sections.

(b) In the second step, we transferred the cross-section reference geometries to the respective vibra-coring positions (Table 2). Here, we used trench bottom levels from recovered core stratigraphies. The specific reference geometry was adjusted to the level of the trench bottom, inferred from individual cores (Figure $4 \mathrm{~b}$ ). If the trench bottom was deeper than the cross-section reference geometry, we extended the embankments with its specific slope angle until they reached the pre-modern DTM surface. If the trench bottom was above the depth of the cross-section reference geometry, we cut the supernatant embankments at the pre-modern DTM surface. 
Table 2. Sections of the Fossa Carolina and corresponding cross-sections reference geometries.

\begin{tabular}{lllll}
\hline Fossa Carolina Section & Length (m) & $\begin{array}{l}\text { Cross-Section } \\
\text { Reference Geometry }\end{array}$ & Type & $\begin{array}{l}\text { Transferred to } n \\
\text { Core Positions }\end{array}$ \\
\hline Central Section & 803 & "WE cross-section" & direct push sensing & 10 \\
WE Section & 494 & "WE cross-section" & direct push sensing & 16 \\
Northern Section I (S) & 368 & "The Anomaly" & direct push sensing & 1 \\
Northern Section II (N) & 370 & "2013" & archaeological excavation & 6 \\
North-Eastern Section I (S) & 476 & "2013" & archaeological excavation & 0 \\
North-Eastern Section II (M) & 198 & "2016-S1" & archaeological excavation & 2 \\
North-Eastern Section III (N) & 120 & "2016-S2" & archaeological excavation & 4 \\
\hline
\end{tabular}

(c) Subsequently, we created additional transects, which were not based on vibra-coring. These additional transects were important for the interpolation of all transects in the next step. The larger the distance between two transects, the bigger the potential interpolation errors and disturbances [55]. For this reason, we added additional transects equidistantly ( $\sim 50 \mathrm{~m}$ spacing) (Figure 2 ). The depths were transferred from neighbouring vibra-coring trench bottom levels, direct push sensing transects or archaeological excavations (Figure 4c).

(d) Once all transects had been calculated, we spatially interpolated neighbouring transects via triangulation with an output raster of $0.5 \mathrm{~m}$ resolution (Figure $4 \mathrm{~d}$ ). Altogether, we interpolated 73 single segments. Finally, we merged all single segments into one raster dataset and used a low-pass filter (5m radius) to slightly smooth the raster data. The result was a 3D digital terrain model of the Fossa Carolina at its maximum construction depth in a $0.5 \times 0.5 \mathrm{~m}$ resolution.

(e) and (f) To answer the question of the volumes, we integrated the 3D-model in the pre-modern landscape (Figure 4e) provided by Schmidt et al. [34]. We determined the excavation volume of the canal trench by calculating the difference between the 3D-model and the pre-modern DTM (Figure 4f). The volume of the Fossa Carolina dam remnants was computed as the difference between the present LiDAR DTM and the pre-modern DTM.

\section{Results}

\subsection{Canal Course}

We localised the canal course with different prospection methods (SQUID magnetic and Fluxgate magnetic prospection as well as DTM analyses), depending on the data availability. In the Central Section, no geophysical data were available due to wet and barley passable ground conditions. Therefore, we used the middle of the dam ridges as alignment of the canal centre (Figure $5 b$ ). In the West-East Section, we used a combination of dam ridge positions and a Fluxgate magnetic map to explore the canal course (Figure 5c). Low relief changes and nearly no visible dams characterise the Northern and North-Eastern Sections. Here, we used SQUID magnetic prospection maps for precisely reconstructing the canal course (Figure $5 \mathrm{~d}$ ). 


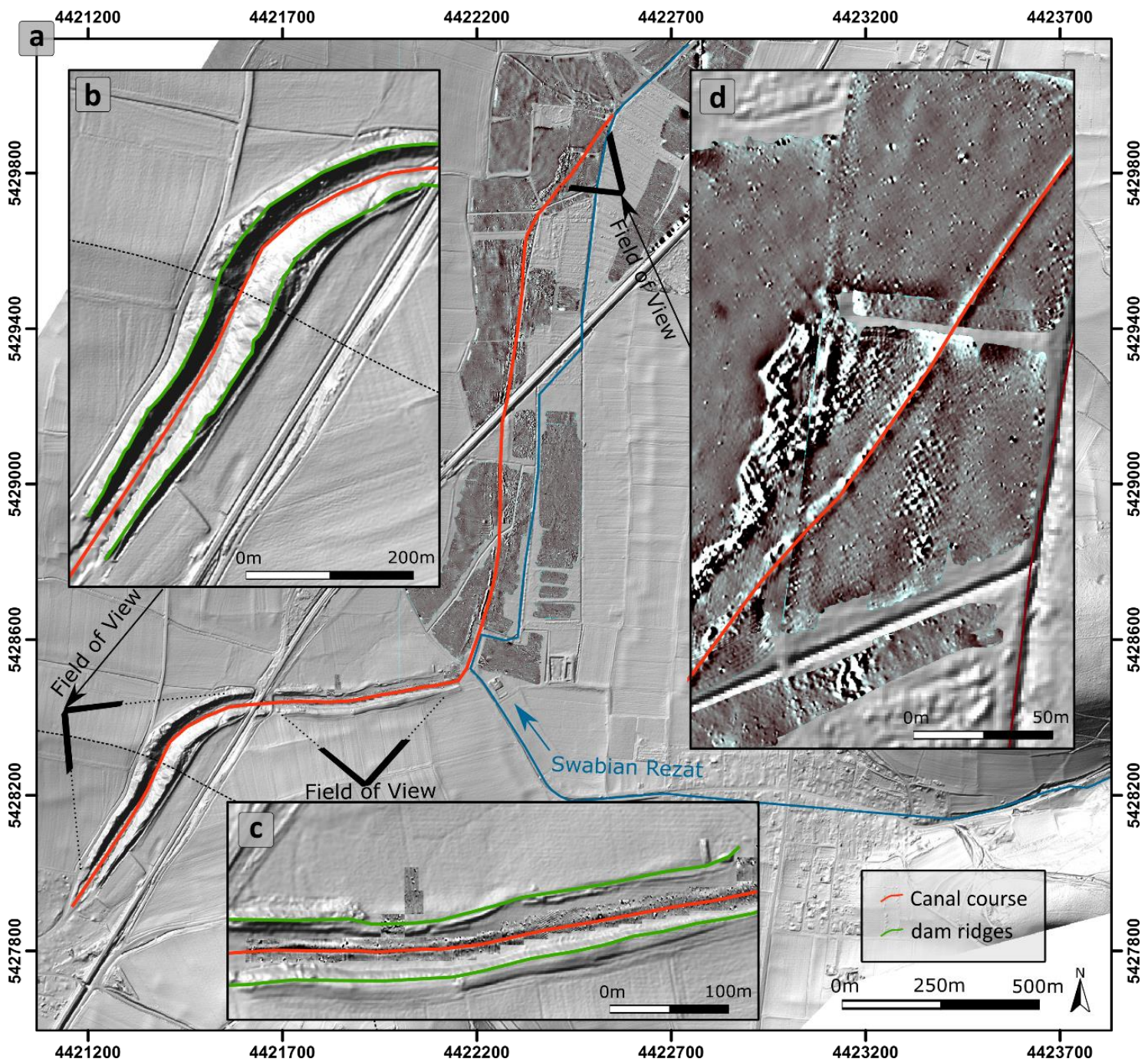

Figure 5. Localisation of the Fossa Carolina course. (a) Total study area, magnetic maps and Digital Terrain Model (DTM) data, (b) Central Section with canal course and dam ridges, (c) West-East Section with canal course, dam ridges and Fluxgate magnetic map, (d) North-Eastern Section with canal course and SQUID (Superconducting Quantum Interference Device) magnetic map, Greyscale: $\pm 10 \mathrm{nT} / \mathrm{m}$.

\subsection{Cross-Section Reference Geometries}

We established five cross-section reference geometries based on two direct push sensing transects and three archaeological excavations. These geometries are the first interim results of our study.

The "WE cross-section" is situated in the western part of the West-East Section of the Fossa Carolina [38] (a in Figure 2; Figure 6). The second direct push sensing cross-section ("The Anomaly") is situated in the Northern Section ( $b$ in Figure 2). We detected the deepest level of the trench bottom at $5.5 \mathrm{~m}$ depth below modern surface (Figure 7). 


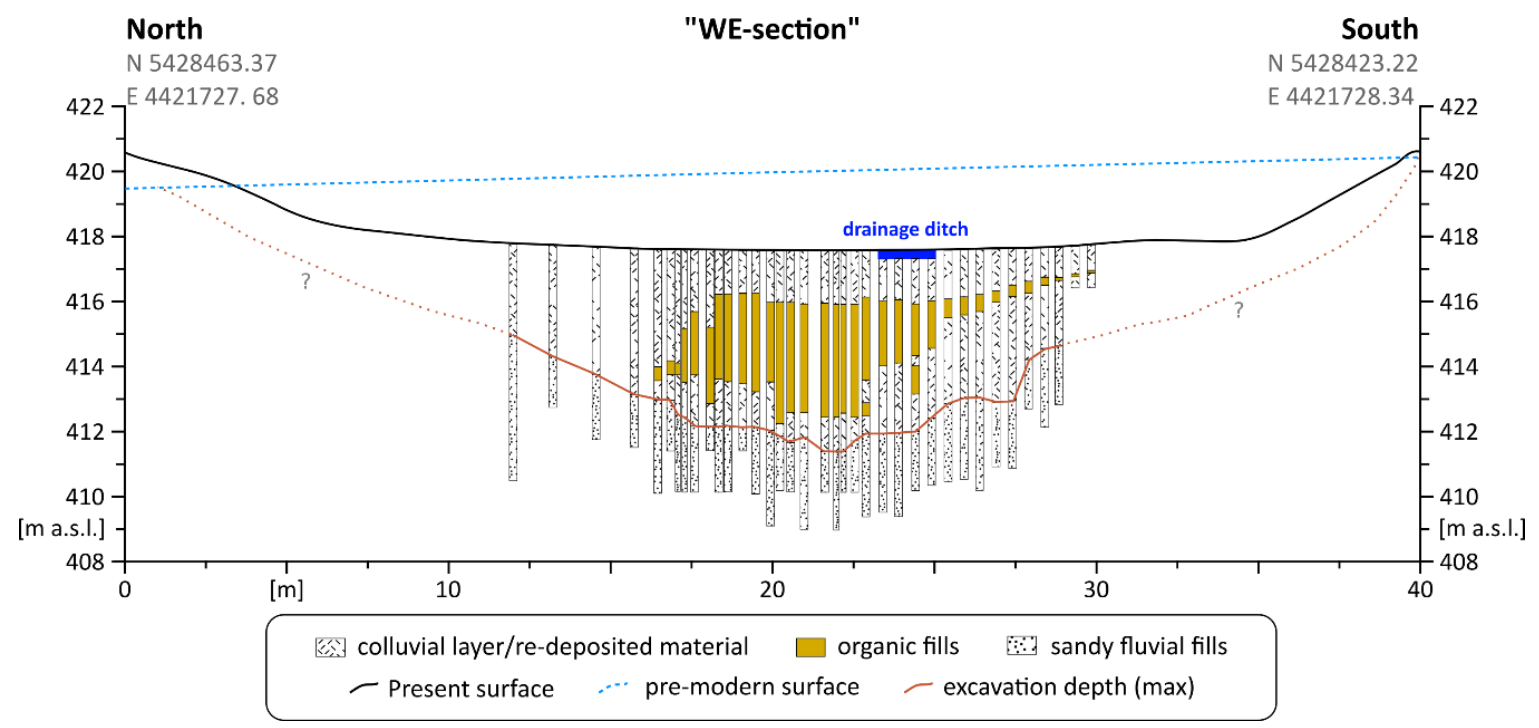

Figure 6. Cross-section reference geometry based on direct push sensing. The sketch of the "WE cross-section" transect shows present and pre-modern surface levels, trench geometries and maximum excavation depth.

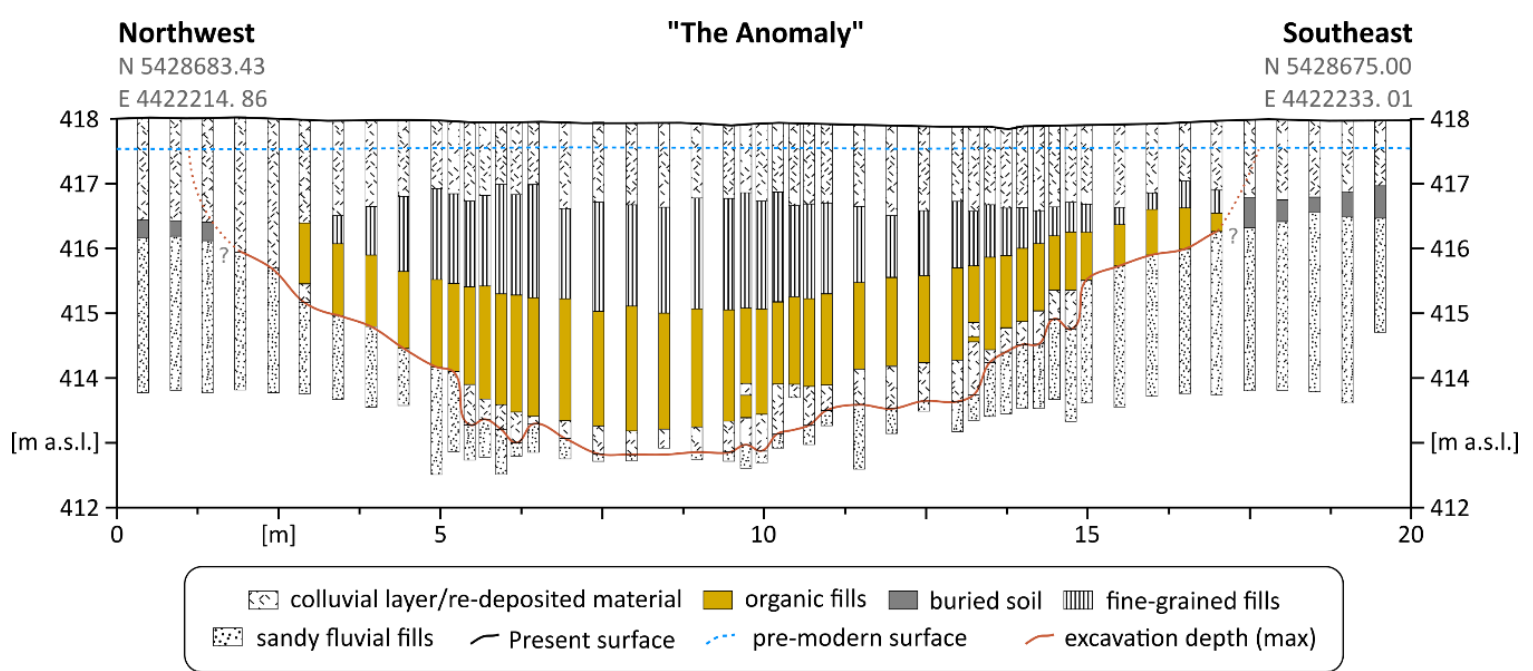

Figure 7. Cross-section reference geometry based on direct push sensing. The sketch of the "The Anomaly" transect shows present and pre-modern surface levels, trench geometries and maximum excavation depth.

About $300 \mathrm{~m}$ further north, we derived a cross-section reference geometry from an archaeological excavation that took place in 2013 (c in Figure 2). The excavation revealed a trench bottom approx. $3 \mathrm{~m}$ below surface (Figure 8a). Another excavation took place in 2016 that provided two cross-section reference geometries in the northernmost part of the canal. At excavation "2016-S1" ( $d$ in Figure 2) the maximum depth of the trench bottom is approx. $2 \mathrm{~m}$ below surface (Figure $8 \mathrm{~b}$ ) and at excavation "2016-S2" (e in Figure 2) the trench bottom was recovered at approx. $1.2 \mathrm{~m}$ below surface (Figure 8c). The general geometry over all cross-sections looks similar. Both cross-sections "2013" and "2016-S1" show fairway width of approx. $5 \mathrm{~m}$ and an almost finished canal construction. In contrast, the cross-section "2016-S2" reveals a fairway width of just approx. $2.5 \mathrm{~m}$. 


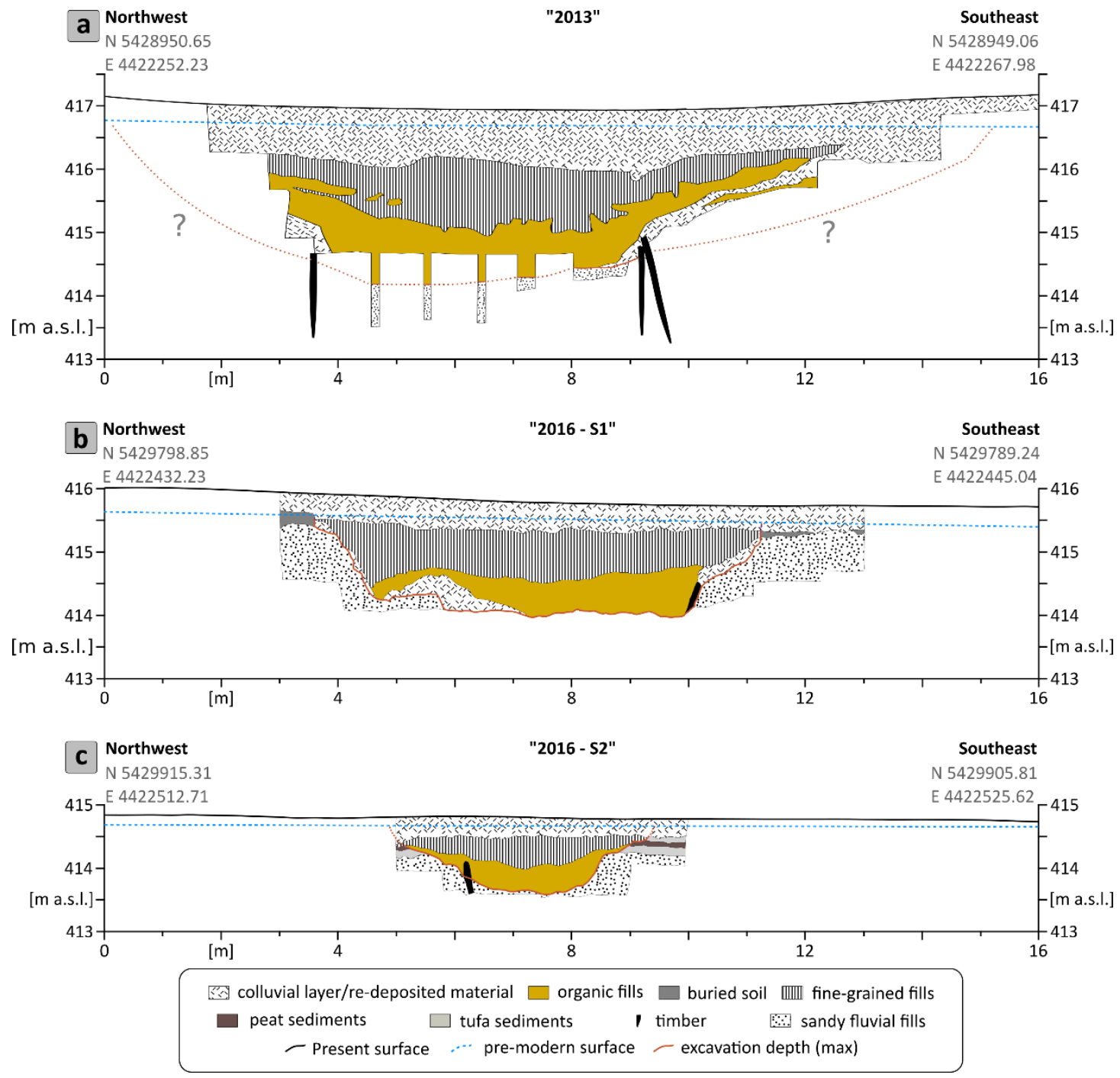

Figure 8. Archaeological excavation reference geometries. (a) “2013", (b) “2016-S1" and (c) "2016-S2".

\subsection{Application of Cross-Section Reference Geometries to Vibra-Coring and Additive Transects}

The application of the cross-section reference geometries to the respective vibra-coring positions and additional trench bottom transects resulted in an interim data set of our study (Figure 9). In total, we created 26 transects based on vibra-coring positions and 42 additional trench bottom transects. 


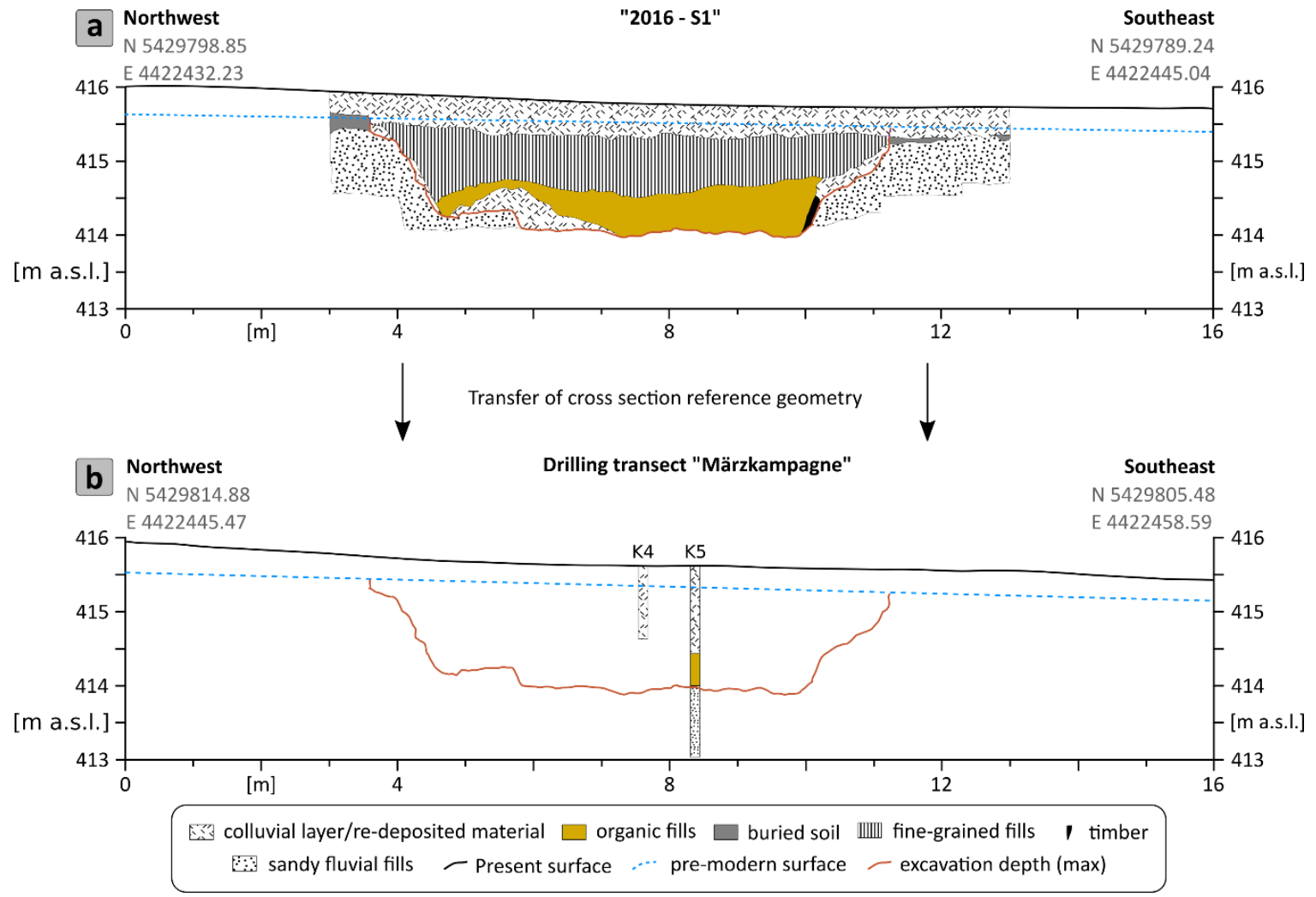

Figure 9. Exemplary transfer of the cross-section reference geometry "2016/S1" to the vibra-coring transect "Märzkampagne".

\subsection{D-Model}

The major step of our study is the development of a 3D-model of the entire Fossa Carolina trench bottom (Figure 10). The interpolation of the all geometry transects resulted in the smooth integration of the canal geometry in the pre-modern landscape. This model is a raster layer and can be used like a DTM within a GIS environment. It has a spatial resolution of $0.5 \times 0.5 \mathrm{~m}$. 


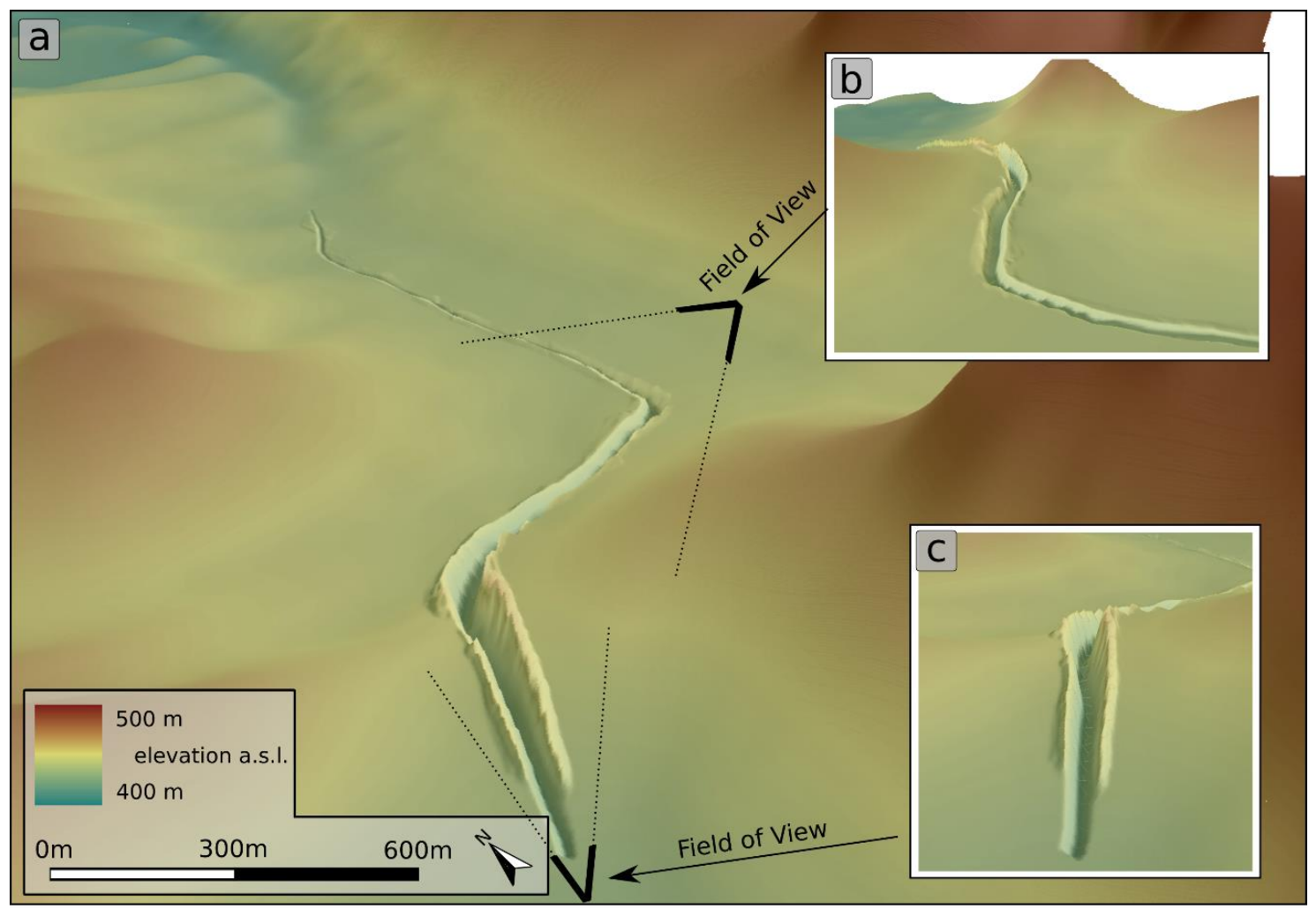

Figure 10. 3D-model of the Fossa Carolina with surrounding pre-modern topography and present remnants of the dams. The 3D-model is 15x exaggerated and its representation method is "perspective". (a) Entire canal course with a view from southeast, (b) enlarged section of the prominent bend between the West-East and Northern Section, (c) enlarged section of the Central Section.

\subsection{Volume Calculation}

The result of the volume calculation can be separated into two data sets. First, the excavation volume calculation is based on the 3D-model of the Fossa Carolina and pre-modern DTM. The material that was moved during the construction has a volume of approx. $297,000 \mathrm{~m}^{3}$. Second, the present remnants of the dams have a volume of approx. $120,000 \mathrm{~m}^{3}$. This calculation is based on the pre-modern DTM and the present LiDAR DTM.

\section{Discussion}

\subsection{D-Modelling Approach and Quality}

Applications of GIS in geoarchaeological issues have become common recently [56,57]. The integration of geoarchaeological data with GIS tools offers various possibilities of data management and analysis [58,59]. However, modelling approaches that aim to reconstruct archaeological features are rare. Here, reconstructions are mainly on a small scale and include available spatial geometry information such as geophysics or excavation data. Smedt et al. [24] used a geophysical survey (electromagnetic induction) to reconstruct a medieval wetland reclamation. Further, Diamanti et al. [26] used geophysical survey data from electrical resistivity tomography to reconstruct buried city ruins. In contrast, Pickett et al. [17] reconstructed a medieval burial mound by means of data from archaeological excavations. Studies with a combination of geoarchaeological techniques are lacking.

For the first time, we developed an approach for the integration of different geoarchaeological data for a large-scale feature of $2.9 \mathrm{~km}$ length. We think that we produced reliable results but we have to discuss the quality and potential sources of uncertainty. The majority of our input data consists of published geoarchaeological cross-sections, archaeological excavations and a pre-modern 
DTM (Table 1). Direct push sensing data and geometric information derived from archaeological excavations provide excellethe trench bottom was recovered at approx. $1.2 \mathrm{~m}$ below nt depth accuracies. Vibra-coring data may have a coarser vertical resolution and uncertainties in depth accuracy due to the compaction of organic sediments [27]. The overall Root Mean Square Error (RMSE) of the pre-modern DTM [34] was calculated using vibra-coring, direct push sensing and archaeological excavation data that recovered a buried paleosol and, therefore, the former level of the pre-modern surface. The RMSE of 0.69 shows a general overestimation of the modelled pre-modern DTM levels $(69 \mathrm{~cm})$. Hence, the computed volume of the Fossa Carolina excavation material can be slightly lower in contrast to the calculated volume of the dams which would increase.

\subsection{The Scientific History of Fossa Carolina Volume Calculations}

First of all, Birzer [10] assumed an excavation volume only for the Central and West-East Section of approx. $80,000 \mathrm{~m}^{3}$. As the author had no reliable information about the total length of the canal, he estimated in the next step a $4.5 \mathrm{~km}$ long canal course with a constant trench bottom level. As a result, he estimated a total volume of approx. $450,000 \mathrm{~m}^{3}$ for the entire canal course (Table 3). Hofmann [60] worked in detail with the building energetics. He hypothesised a single trench bottom level and no summit concept. With a length of $1.4 \mathrm{~km}$, a $30 \mathrm{~m}$ width and an assumed depth of $6 \mathrm{~m}$, he calculated a volume of approx. 130,000 $\mathrm{m}^{3}$. The most recent volume estimation is from Koch [8]. He drilled several cores and recovered that the detected trench bottom levels do not reach the level of the Altmühl River. Therefore, he concluded that the canal was presumably constructed as a summit canal and carefully assumed roughly several $100,000 \mathrm{~m}^{3}$ of excavation material (Table 3).

Table 3. Scientific history of Fossa Carolina volume estimations.

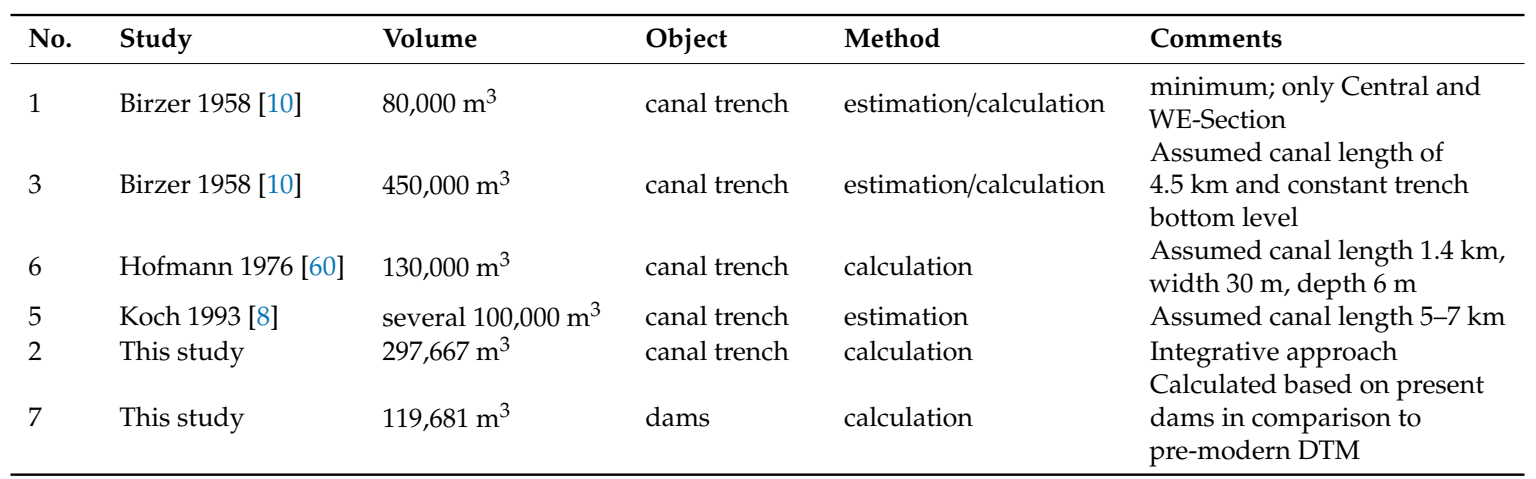

Our study presents for the first time a 3D-modelling approach that is based on precise excavation, vibra-coring and direct push sensing data sets. The resulting volume of approx. 297,000 $\mathrm{m}^{3}$ represents an improved calculation in comparison with former estimations. With respect to the summit concept, no other authors assumed a volume as large as we calculated. We can summarise that the former lack of geoarchaeological data led to uncertain conclusions. Furthermore, this precise volume calculation is key for reliable future modelling of building energetics of this unique canal construction.

The spatial distribution of the excavated volume shows that the majority (54\%) was excavated in the Central Section (Figure 11). Further, the West-East Section has a proportion of roughly $32 \%$ of the volume and only $14 \%$ corresponds with the Northern and North-Eastern Sections (Table 4). 


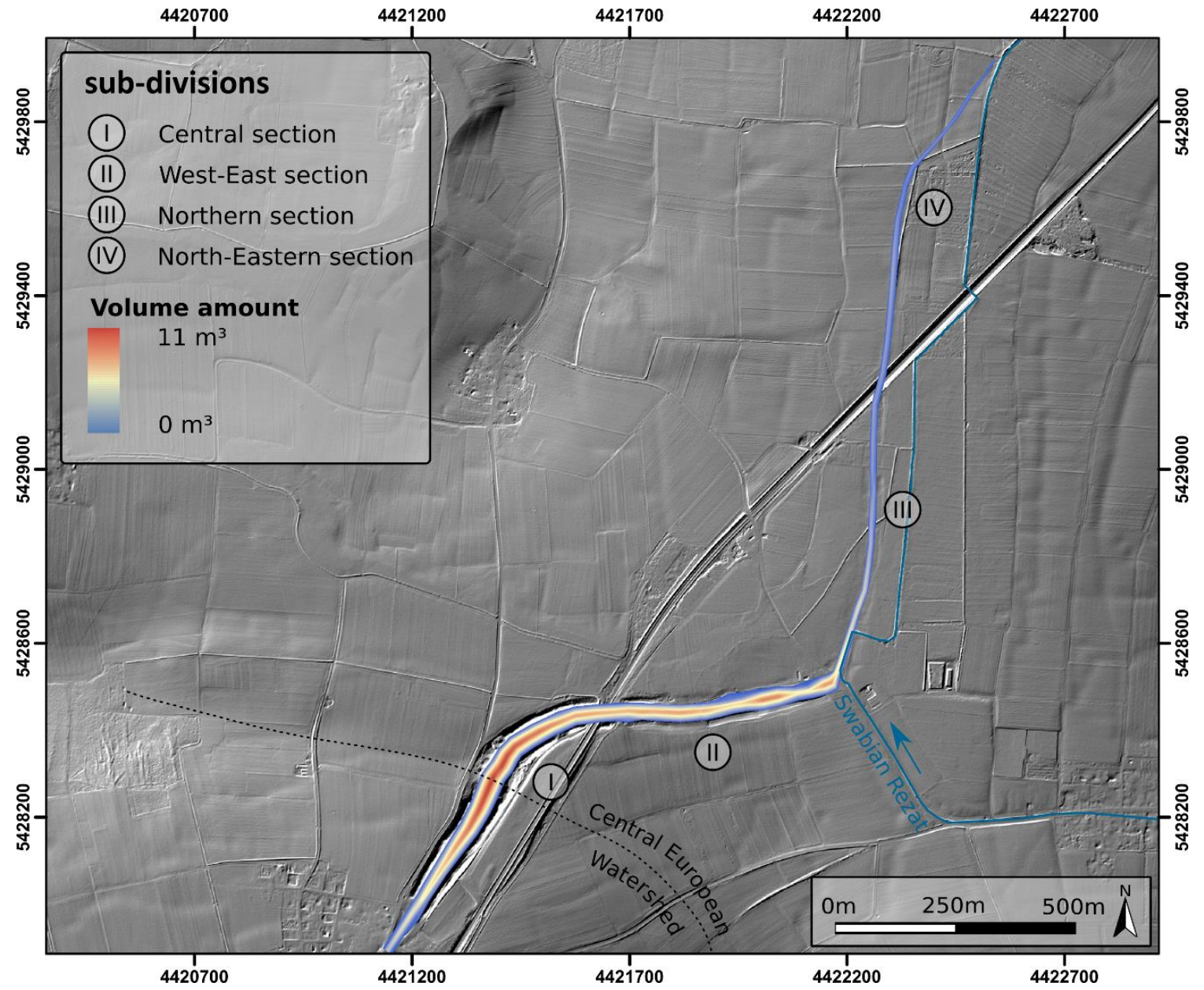

Figure 11. Spatial distribution of excavated volume of the Fossa Carolina. Volume amounts are given in $\mathrm{m}^{3}$ per cell $\left(0.25 \mathrm{~m}^{2}\right)$.

Table 4. Relative amounts of excavated volume of individual Fossa Carolina sections.

\begin{tabular}{lllllll}
\hline Section & $\begin{array}{l}\text { Section } \\
\text { Length }\end{array}$ & $\begin{array}{l}\text { Length } \\
\text { Proportion }\end{array}$ & $\begin{array}{l}\text { Trench } \\
\text { Volume }\end{array}$ & $\begin{array}{l}\text { Trench Volume } \\
\text { Proportion }\end{array}$ & $\begin{array}{l}\text { Dam } \\
\text { Volume }\end{array}$ & $\begin{array}{l}\text { Ratio } \\
\text { Dams/Trench }\end{array}$ \\
\hline Total & $2829 \mathrm{~m}$ & $100 \%$ & $297,667 \mathrm{~m}^{3}$ & $100 \%$ & $119,681 \mathrm{~m}^{3}$ & $40 \%$ \\
Central Section & $803 \mathrm{~m}$ & $28 \%$ & $160,815 \mathrm{~m}^{3}$ & $54 \%$ & $83,826 \mathrm{~m}^{3}$ & $52 \%$ \\
WE Section & $494 \mathrm{~m}$ & $17 \%$ & $96,496 \mathrm{~m}^{3}$ & $32 \%$ & $20,449 \mathrm{~m}^{3}$ & $21 \%$ \\
Northern Section & $738 \mathrm{~m}$ & $27 \%$ & $26,267 \mathrm{~m}^{3}$ & $9 \%$ & $10,864 \mathrm{~m}^{3}$ & $41 \%$ \\
North-Eastern & $794 \mathrm{~m}$ & $27 \%$ & $14,088 \mathrm{~m}^{3}$ & $5 \%$ & $4,558 \mathrm{~m}^{3}$ & $32 \%$ \\
Section & & & & & & \\
\hline
\end{tabular}

\subsection{Where Has All the Material Gone?}

It is obvious that more than half of the excavated volume is not stored in the remaining dams. Vibra-coring [40], direct push sensing [38] and archaeological excavation data [33] show that significant amounts of excavated material was already washed back into the open trench shortly after the construction site was abandoned. Upper trench fills reflect relocated material originating from the adjacent dams [32]. The canal and the corresponding dams were fundamentally modified even during modern times. Especially the northern canal sections, which were levelled for agricultural purposes [61] and missing dam volumes in the central canal sections result from massive sand and loam mining activities for modern infrastructure and buildings [6,34]. 


\section{Conclusions}

Our 3D-modelling approach of the Early Medieval Fossa Carolina integrates archaeological excavations, direct push sensing and vibra-coring techniques, as well as the present LiDAR DTM, Fluxgate and SQUID magnetic surveys and a paleo-surface (pre-modern DTM) of the study area. We identified the buried canal trench by LiDAR DTM analysis of the present dam remnants and interpretation of magnetic survey maps. We transferred cross-section reference geometries (derived from archaeological excavations and direct push sensing transects) to vibra-coring positions. Finally, we interpolated the canal trench geometry to create the 3D-model of the Carolingian canal. The spatial and vertical accuracy of the model depends on the quality of its input data. The reference cross-sections are of high quality as well as the LiDAR DTM and pre-modern DTM. Because of the large spatial extent of the canal, we included several vibra-corings, which have at least cm depth accuracy. Our modelling routine minimises the uncertainties by creating cross-section reference geometries.

For the first time, the 3D-model provides a data-based calculation of the amount of material moved during the Early Medieval construction. The calculation of the earth volume was done by calculating the difference between the 3D-model and the pre-modern digital terrain model. The pre-modern DTM reflects a deconstructed landscape nearly free of human induced terrain changes. Altogether, approx. $297,000 \mathrm{~m}^{3}$ of material was excavated during the Early Medieval construction time.

In comparison, we calculated the volume of the preserved dams. This was also done by subtracting the present shape from the pre-modern DTM. Approximately $120,000 \mathrm{~m}^{3}$ material still remains in the dams. Nevertheless, more than the half of the excavation material was eroded, redistributed, or backfilled in the canal.

Author Contributions: Conceptualisation, J.S.; methodology, J.S., L.W. and C.Z.; data acquisition, J.S., J.R.-V., L.W., S.L., A.S., B.S., U.W., C.Z.; data analysis; J.S. with feedback from all co-authors; writing-original draft preparation, J.S.; writing-review and editing, J.S., L.W. and C.Z.; funding acquisition, C.Z., P.E., S.L., S.B. and P.D. All co-authors read and approved the submitted manuscript, agreed to be listed, and accepted the version for publication.

Funding: This research was funded by the German Research Foundation (DFG), grant numbers ZI 721/10-2, ET 20/7-2, DI 833/19-1. The Article Processing Charge (APC) was funded by the German Research Foundation and Leipzig University within the program of Open Access publishing.

Acknowledgments: The authors are thankful to the Germany Research Foundation (DFG) for financial and logistic support in the scope of the DFG priority program 1630 (ZI 721/10-2, ET 20/7-2, DI 833/19-1). Furthermore, we would like to thank the Bavarian State Department of Monuments and Sites for logistic and financial support and the Bavarian State Office for Land Surveying for providing geodata. We are thankful to Marco Holzheu and multiple students from Leipzig Institute of Geography for their support during field work. We acknowledge support from the German Research Foundation and Leipzig University within the program of Open Access Publishing. Finally, we thank the reviewers and editors for their help improving the manuscript.

Conflicts of Interest: The authors declare no conflict of interest.

\section{References}

1. McCormick, M. The Origin of the European Economy. Communications and Commerce A.D. 300-900; Cambridge University Press: Cambridge, UK, 2010.

2. Squatriti, P. Digging Ditches in Early Medieval Europe. Past Present 2002, 176, 11-65. [CrossRef]

3. Leitholdt, E.; Zielhofer, C.; Berg-Hobohm, S.; Schnabl, K.; Kopecky-Hermanns, B.; Bussmann, J.; Härtling, J.W.; Reicherter, K.; Unger, K. Fossa Carolina: The First Attempt to Bridge the Central European Watershed-A Review, New Findings, and Geoarchaeological Challenges. Geoarchaeology 2012, 27, 88-104. [CrossRef]

4. Werther, L.; Kröger, L.; Kirchner, A.; Zielhofer, C.; Leitholdt, E.; Schneider, M.; Linzen, S.; Berg-Hobohm, S.; Ettel, P. Fossata Magna-A Canal Contribution to Harbour Construction in the 1st Millenium AD. In Harbours as Object of Interdisciplinary Research: Archaeology + History + Geosciences; Carnap-Bornheim, C.V., Daim, F., Ettel, P., Warnke, U., Eds.; Verl. des RGZM: Mainz, Germany, 2018; pp. 355-372, ISBN 9783884672839. 
5. Preiser-Kapeller, J.; Werther, L. Connecting Harbours: A Comparison of Traffic Networks across Ancient and Medieval Europe. In Harbours as Object of Interdisciplinary Research: Archaeology + History + Geosciences; Carnap-Bornheim, C.V., Daim, F., Ettel, P., Warnke, U., Eds.; Verl. des RGZM: Mainz, Germany, 2018; pp. 7-31, ISBN 9783884672839.

6. Beck, F. Der Karlsgraben Eine Historische, Topographische und Kritische Abhandlung. Mit Beilagen; Verlag der Friedrich Kornschen Buchhandlung: Nürnberg, Germany, 1911.

7. Berg-Hobohm, S. Archäologische Forschungsgeschichte der Fossa Carolina. In Großbaustelle 793: Das Kanalprojekt Karls des Großen zwischen Rhein und Donau; Ettel, P., Berg-Hobohm, S., Eds.; Verl. des Römisch-Germanischen Zentralmuseums: Mainz, Germany, 2014; pp. 1-4, ISBN 978-3-88467-232-7.

8. Koch, R. Fossa Carolina-1200 Jahre Karlsgraben; Denkmalpflege Informationen: München, Germany, 1993.

9. Koch, R. Neue Beobachtungen und Forschungen zum Karlsgraben. Jahrbuch des Historischen Vereins für Mittelfranken 1996, 97, 1-16.

10. Birzer, F. Der Kanalbauversuch Karls des Großen. Geologische Blätter für Nordost-Bayern und Angrenzende Gebiete 1958, 8, 171-178.

11. Bruno, F.; Bruno, S.; de Sensi, G.; Luchi, M.-L.; Mancuso, S.; Muzzupappa, M. From 3D reconstruction to virtual reality: A complete methodology for digital archaeological exhibition. J. Cult. Herit. 2010, 11, 42-49. [CrossRef]

12. De Reu, J.; de Smedt, P.; Herremans, D.; van Meirvenne, M.; Laloo, P.; de Clercq, W. On introducing an image-based 3D reconstruction method in archaeological excavation practice. J. Archaeol. Sci. 2014, 41, 251-262. [CrossRef]

13. Ducke, B.; Score, D.; Reeves, J. Multiview 3D reconstruction of the archaeological site at Weymouth from image series. Comput. Graph. 2011, 35, 375-382. [CrossRef]

14. Richards-Rissetto, H. What can GIS + 3D mean for landscape archaeology? J. Archaeol. Sci. 2017, 84, 10-21. [CrossRef]

15. Forte, M. Virtual Reality, Cyberarchaeoloogy, teleimmersive Archaeology. In 3D Recording and Modelling in Archaeology and Cultural Heritage: Theory and Best Practises; Remondino, F., Campana, S., Eds.; Archaeopress: Oxford, UK, 2014; pp. 113-127.

16. Koutsoudis, A.; Arnaoutoglou, F.; Chamzas, C. On 3D reconstruction of the old city of Xanthi. A minimum budget approach to virtual touring based on photogrammetry. J. Cult. Herit. 2007, 8, 26-31. [CrossRef]

17. Pickett, J.; Schreck, J.S.; Holod, R.; Rassamakin, Y.; Halenko, O.; Woodfin, W. Architectural energetics for tumuli construction: The case of the medieval Chungul Kurgan on the Eurasian steppe. J. Archaeol. Sci. 2016, 75, 101-114. [CrossRef]

18. Lacquement, C.H. Recalculating mound volume at moundville. Southeast. Archaeol. 2010, 29, 341-354. [CrossRef]

19. Sherwood, S.C.; Kidder, T.R. The DaVincis of dirt: Geoarchaeological perspectives on Native American mound building in the Mississippi River basin. J. Anthropol. Archaeol. 2011, 30, 69-87. [CrossRef]

20. Zielhofer, C.; Wellbrock, K.; Al-Souliman, A.S.; von Grafenstein, M.; Schneider, B.; Fitzsimmons, K.; Stele, A.; Lauer, T.; Von Suchodoletz, H.; Grottker, M. Climate forcing and shifts in water management on the Northwest Arabian Peninsula (mid-Holocene Rasif wetlands, Saudi Arabia). Quat. Int. 2018, 473, 120-140. [CrossRef]

21. Grammer, B.; Draganits, E.; Gretscher, M.; Muss, U. LiDAR-guided Archaeological Survey of a Mediterranean Landscape: Lessons from the Ancient Greek Polis of Kolophon (Ionia, Western Anatolia). Archaeol. Prospect. 2017, 54, 64. [CrossRef]

22. Cowley, D.; Moriarty, C.; Geddes, G.; Brown, G.; Wade, T.; Nichol, C. UAVs in Context: Archaeological Airborne Recording in a National Body of Survey and Record. Drones 2018, 2, 2. [CrossRef]

23. Andersen, N.H. The Sarup Enclosures. The Funnel Beaker Culture of the Sarup Site including Two Causewaysed Camps Compared to the Contemporary Settlements in the Area and other European Enclosures; Aarhus University Press: Aarhus, Denmark, 1997.

24. DeSmedt, P.; van Meirvenne, M.; Herremans, D.; de Reu, J.; Saey, T.; Meerschman, E.; Crombé, P.; de Clercq, W. The 3-D reconstruction of medieval wetland reclamation through electromagnetic induction survey. Sci. Rep. 2013, 3, 1517. [CrossRef]

25. De Smedt, P.; van Meirvenne, M.; Meerschman, E.; Saey, T.; Bats, M.; Court-Picon, M.; de Reu, J.; Zwertvaegher, A.; Antrop, M.; Bourgeois, J.; et al. Reconstructing palaeochannel morphology with a mobile multicoil electromagnetic induction sensor. Geomorphology 2011, 130, 136-141. [CrossRef] 
26. Diamanti, N.G.; Tsokas, G.N.; Tsourlos, P.I.; Vafidis, A. Integrated interpretation of geophysical data in the archaeological site of Europos (northern Greece). Archaeol. Prospect. 2005, 12, 79-91. [CrossRef]

27. Hausmann, J.; Zielhofer, C.; Werther, L.; Berg-Hobohm, S.; Dietrich, P.; Heymann, R.; Werban, U. Direct push sensing in wetland (geo)archaeology: High-resolution reconstruction of buried canal structures (Fossa Carolina, Germany). Quat. Int. 2017, 473, 21-36. [CrossRef]

28. Hadler, H.; Vött, A.; Newig, J.; Emde, K.; Finkler, C.; Fischer, P.; Willershäuser, T. Geoarchaeological evidence of marshland destruction in the area of Rungholt, present-day Wadden Sea around Hallig Südfall (North Frisia, Germany), by the Grote Mandrenke in 1362 AD. Quat. Int. 2018, 473, 37-54. [CrossRef]

29. Seeliger, M.; Pint, A.; Frenzel, P.; Weisenseel, P.; Erkul, E.; Wilken, D.; Wunderlich, T.; Başaran, S.; Bücherl, H.; Herbrecht, M. Using a Multi-Proxy Approach to Detect and Date a Buried part of the Hellenistic City Wall of Ainos (NW Turkey). Geosciences 2018, 8, 357. [CrossRef]

30. Canti, M.; Huisman, D.J. Scientific advances in geoarchaeology during the last twenty years. J. Archaeol. Sci. 2015, 56, 96-108. [CrossRef]

31. Beuzen-Waller, T.; Stock, F.; Kondo, Y. Geoarchaeology: A toolbox for revealing latent data in sedimentological and archaeological records. Quat. Int. 2018, 483,1-4. [CrossRef]

32. Zielhofer, C.; Leitholdt, E.; Werther, L.; Stele, A.; Bussmann, J.; Linzen, S.; Schneider, M.; Meyer, C.; Berg-Hobohm, S.; Ettel, P. Charlemagne's summit canal: An early medieval hydro-engineering project for passing the Central European Watershed. PLoS ONE 2014, 9, e108194. [CrossRef] [PubMed]

33. Werther, L.; Feiner, D. Der Karlsgraben im Fokus der Archäologie. In Großbaustelle 793: Das Kanalprojekt Karls des Großen Zwischen Rhein und Donau; Ettel, P., Berg-Hobohm, S., Eds.; Verl. des Römisch-Germanischen Zentralmuseums: Mainz, Germany, 2014; pp. 33-40, ISBN 978-3-88467-232-7.

34. Schmidt, J.; Werther, L.; Zielhofer, C. Shaping pre-modern digital terrain models: The former topography at Charlemagne's canal construction site. PLoS ONE 2018, 13, e0200167. [CrossRef] [PubMed]

35. Zielhofer, C.; Rabbel, W.; Wunderlich, T.; Vött, A.; Berg, S. Integrated geophysical and (geo)archaeological explorations in wetlands. Quat. Int. 2018, 473,1-2. [CrossRef]

36. Werther, L.; Zielhofer, C.; Herzig, F.; Leitholdt, E.; Schneider, M.; Linzen, S.; Berg-Hobohm, S.; Ettel, P.; Kirchner, A.; Dunkel, S. Häfen verbinden. Neue Befunde zu Verlauf, wasserbaulichem Konzept und Verlandung des Karlsgrabens. In Häfen im 1. Millennium AD: Bauliche Konzepte, Herrschaftliche und Religiöse Einflüsse, 1st ed.; Schmidts, T., Vučetić, M.M., Eds.; Schnell \& Steiner; Verl. des RGZM: Regensburg, Mainz, Germany, 2015; pp. 151-185, ISBN 978-3-7954-3039-9.

37. Werther, L. Karlsgraben doch Schiffbar? Aktuelles aus der Landesarchäologie. Archäologie Deutschland 2017, 5, 41-42.

38. Völlmer, J.; Zielhofer, C.; Hausmann, J.; Dietrich, P.; Werban, U.; Schmidt, J.; Werther, L.; Berg, S. Minimalinvasive Direct-push Erkundung in der Feuchtboden(geo)archäologie am Beispiel des Karlsgrabens (Fossa Carolina). Archäologisches Korrespondenzblatt 2018, 48, 577-593.

39. Leitholdt, E.; Krüger, A.; Zielhofer, C. The medieval peat layer of the Fossa Carolina-Evidence for bridging the Central European Watershed or climate control? Z. Geomorphol. Suppl. Issues 2014, 58, 189-209. [CrossRef]

40. Kirchner, A.; Zielhofer, C.; Werther, L.; Schneider, M.; Linzen, S.; Wilken, D.; Wunderlich, T.; Rabbel, W.; Meyer, C.; Schmidt, J.; et al. A multidisciplinary approach in wetland geoarchaeology: Survey of the missing southern canal connection of the Fossa Carolina (SW Germany). Quat. Int. 2018, 473, 3-20. [CrossRef]

41. Schmidt-Kaler, H. Geologie und Landschaftsentwicklung im Rezat-Altmühl Bereich; Bau intern Special Issue; Lipp: München, Germany, 1993; pp. 8-10.

42. Zielhofer, C.; Kirchner, A. Naturräumliche Gunstlage der Fossa Carolina. In Großbaustelle 793: Das Kanalprojekt Karls des Großen zwischen Rhein und Donau; Ettel, P., Berg-Hobohm, S., Eds.; Verl. des Römisch-Germanischen Zentralmuseums: Mainz, Germany, 2014; pp. 5-8, ISBN 978-3-88467-232-7.

43. Bavarian State Department of Cultural Heritage BLfD.; Luftbildarchiv, Archivnummer: 7130_027, Filmnummer: 3840B, Bild 12, 19.02.1985, 1985. Available online: https://www.ldbv.bayern.de/vermessung/ luftbilder/archiv.html (accessed on 13 May 2013).

44. Bavarian Land Surveying Office. Geländemodell. 2018. Available online: https://www.ldbv.bayern.de/ produkte/3dprodukte/gelaende.html (accessed on 12 April 2019).

45. Bavarian Land Surveying Office. Airborne Laserscanning. 2018. Available online: https://www.ldbv.bayern. de/produkte/3dprodukte/laser.html (accessed on 12 April 2019). 
46. Linzen, S.; Schultze, V.; Chwala, A.; Schüler, T.; Schulz, M.; Stolz, R.; Meyer, H.-G. Quantum Detection Meets Archaeology-Magnetic Prospection with SQUIDs, Highly Sensitive and Fast. In New Technologies for Archaeology; Reindel, M., Wagner, G.A., Eds.; Springer: Berlin/Heidelberg, Germany, 2009; pp. 71-85.

47. Schneider, M.; Stolz, R.; Linzen, S.; Schiffler, M.; Chwala, A.; Schulz, M.; Dunkel, S.; Meyer, H.-G. Inversion of geo-magnetic full-tensor gradiometer data. J. Appl. Geophys. 2013, 92, 57-67. [CrossRef]

48. Linzen, S.; Schneider, M.; Berg-Hobohm, S.; Werther, L.; Ettel, P.; Zielhofer, C.; Schmidt, J.; Fassbinder, J.W.E.; Wilken, D.; Fediuk, A.; et al. From magnetic SQUID prospection to excavation-Investigations at Fossa Carolina, Germany. In Proceedings of the 12th International Conference of Archaeoloigcal Prospection, Bradford, UK, 12-16 September 2017; Jennings, B., Gaffney, C., Sparrow, T., Gaffney, S., Eds.; Archaeopress: Oxford, UK, 2017; pp. 144-145, ISBN 9781784916770.

49. Linzen, S.; Schneider, M. Der Karlsgraben im Fokus der Geophysik. In Großbaustelle 793: Das Kanalprojekt Karls des Großen zwischen Rhein und Donau; Ettel, P., Berg-Hobohm, S., Eds.; Verl. des Römisch-Germanischen Zentralmuseums: Mainz, Germany, 2014; pp. 29-32, ISBN 978-3-88467-232-7.

50. Dietrich, P.; Leven, C. Direct Push-Technologies. In Groundwater Geophysics, 2nd ed.; Kirsch, R., Ed.; Springer: Berlin, Germany, 2009; pp. 347-366.

51. Leven, C.; Weiß, H.; Vienken, T.; Dietrich, P. Direct-Push-Technologien-Effiziente Untersuchungsmethoden für die Untergrunderkundung. Grundwasser 2011, 16, 221-234. [CrossRef]

52. Hausmann, J.; Dietrich, P.; Vienken, T.; Werban, U. Technique, analysis routines, and application of direct push-driven in situ color logging. Environ. Earth Sci. 2016, 75, 659. [CrossRef]

53. Butler, J.J.; Healey, J.M.; Zheng, L.; McCall, G.W.; Schulmeister, M.K. Hydrostratigraphic Characterization of Unconsolidated Alluvial Deposits with Direct-Push Sensor Technology; Kansas Geological Survey Open-File report 99-40; University of Kansas Field Station: Lawrence, KS, USA, 1999.

54. Schulmeister, M.K.; Butler, J.J.; Healey, J.M.; Zheng, L.; Wysocki, D.A.; McCall, G.W. Direct-Push Electrical Conductivity Logging for High-Resolution Hydrostratigraphic Characterization. Groundw. Monit. Remediat. 2003, 23, 52-62. [CrossRef]

55. Davis, J.C.; Herzfeld, U.C. Computers in Geology. 25 Years of Progress; Oxford University Press: New York, NY, USA, 1993; ISBN 0195085930.

56. Carey, C.; Howard, A.J.; Knight, D.; Corcoran, J.; Heathcote, J. Deposit Modelling and Archaeology; University of Brighton: Brighton, UK, 2018; ISBN 978-1-5272-2244-1.

57. Earley-Spadoni, T. Spatial History, deep mapping and digital storytelling: Archaeology's future imagined through an engagement with the Digital Humanities. J. Archaeol. Sci. 2017, 84, 95-102. [CrossRef]

58. Chapman, H.; Adcock, J.; Gater, J. An approach to mapping buried prehistoric palaeosols of the Atlantic seaboard in Northwest Europe using GPR, geoarchaeology and GIS and the implications for heritage management. J. Archaeol. Sci. 2009, 36, 2308-2313. [CrossRef]

59. McCoy, M.D. Geospatial Big Data and archaeology: Prospects and problems too great to ignore. J. Archaeol. Sci. 2017, 84, 74-94. [CrossRef]

60. Hofmann, H.H. Kaiser Karls Kanalbau: “Wie Künig Carl der Grosse unterstünde die Donaw vnd den Rhein zusamenzugraben", 2nd ed.; Thorbecke: Sigmaringen, Germany, 1976; ISBN 3-7995-4014-8.

61. Berg-Hobohm, S.; Werther, L. Das rezente Erscheinungsbild des Karlsgrabens. In Großbaustelle 793: Das Kanalprojekt Karls des Großen Zwischen Rhein und Donau; Ettel, P., Berg-Hobohm, S., Eds.; Verl. des Römisch-Germanischen Zentralmuseums: Mainz, Germany, 2014; pp. 9-12, ISBN 978-3-88467-232-7.

(C) 2019 by the authors. Licensee MDPI, Basel, Switzerland. This article is an open access article distributed under the terms and conditions of the Creative Commons Attribution (CC BY) license (http://creativecommons.org/licenses/by/4.0/). 